\title{
Kinga Tutak, $O$ dedykacjach $w$ drukach polskich XVI $i$ XVII w. (grafia i interpunkcja), Księgarnia Akademicka, Kraków 2013, ss. 194
}

Choć recenzowana rozprawa ma charakter interdyscyplinarny, przede wszystkim sytuuje się na obszarze językoznawstwa, dokładniej - na obszarze takich jego subdyscyplin, jak historia języka i jej pogranicze w postaci filologii staropolskiej (ze względu na „historyczny” przedmiot badań), a także lingwistyka tekstu i genologia lingwistyczna (ze względu na sposób ujęcia tego przedmiotu badań). Sama autorka tak trafnie i zasadnie charakteryzuje i sytuuje swoje badania: ,[...] gdy otworzymy dawną książkę [...], naszą uwagę przyciągnie rozbudowany, liczący kilka, a nawet kilkanaście kart utwór dedykacyjny, wpisany w bardzo niekiedy bogatą ramę wydawniczą. Owe dedykacje wyróżniają się kształtem graficzno-typograficznym, czcionką, inną z reguły niż ta, którą złożono tekst dzieła. Czcionka o różnym kroju i stopniu występuje też w samym utworze dedykacyjnym. Uwagę [...] przyciąga również interpunkcja i to nie tyle za sprawa odmiennych znaków [...], ile z powodu odmiennej zasady, rządzącej użyciem znaków przestankowych. Analizie tych właśnie, graficzno-typograficznych i interpunkcyjnych składników tekstów dedykacyjnych w dawnej książce jest poświęcone niniejsze studium.

Tak zakrojone badania nad dedykacjami XVI i XVII wieku sytuują się na pograniczu trzech dziedzin wiedzy humanistycznej: historii literatury (czy szerzej piśmiennictwa), bibliologii i językoznawstwa. Nawiązuję do osiągnięć dwóch pierwszych dyscyplin, ale za nadrzędne uznaję instrumentarium metodologiczne i terminologiczne wypracowane przez językoznawstwo, ściślej przez lingwistykę tekstu" [Tutak 2013: 10].

Rozprawa Kingi Tutak zasługuje na wnikliwą uwagę przedstawicieli wszystkich wskazanych wyżej dyscyplin naukowych. Przesądzają o tym takie jej aspekty (stanowiące o jej bezspornej wielkiej wartości), jak: 
A. Wybór tematu. Generalnie trzeba stwierdzić, że płaszczyzna pisowniowa (a w szczególności graficzna, typograficzna i interpunkcyjna) długo budziła relatywnie najmniejsze zainteresowanie historyków języka. Mimo widocznego od początków XXI wieku [zob. Lisowski 2001; Kuźmicki, Osiewicz, red. 2010; Osiewicz 2013 itp.] wzrostu zainteresowania tym wycinkiem historii języka ojczystego, o roli wyróżnień typograficznych i uzusu interpunkcyjnego w dawnych drukach wiemy wciąż jeszcze stosunkowo niewiele, a ponadto dawniejsze prace dotyczące tego obszaru były zorientowane na fonetyczno-fonologiczną interpretację graficznego kształtu dzieła, podczas gdy Kinga Tutak koncentruje się na jego relewancji kompozycyjnej, a więc na jego konsekwencjach semantycznych i stylistycznych (artystycznych).

B. Solidne podstawy źródłowo-materiałowe rozprawy. „Korpus materiałowy niniejszego opracowania obejmuje dedykacje drukowane, towarzyszące szesnasto- i siedemnastowieczne dziełom, które reprezentują piśmiennictwo użytkowe i artystyczne" [Tutak 2013: 11].

C. Adekwatna do zgromadzonego materiału synkretyczna metodologia, stanowiąca organiczne połączenie analizy filologicznej (o paleograficznych kompetencjach autorki jeszcze niżej) i instrumentarium badawczego lingwistyki tekstu i genologii lingwistycznej.

D. Szerokie tło kulturowe, historycznoliterackie i bibliologiczne opisów, analiz i interpretacji lingwistycznych.

E. Budząca uznanie, a dziś już wyjątkowa (nawet wśród historyków języka polskiego) orientacja autorki w problematyce dawnego pisma. O ile każdy językoznawca diachronista odróżni oczywiście antykwę i kursywę od gotyku, o tyle już umiejętność odróżnienia takich odmian pisma gotyckiego, jak szwabacha i fraktura jest dzisiaj rzadkością.

F. Budzące uznanie zaplecze erudycyjne rozprawy, którego wyrazem jest choćby imponujący wykaz multidyscyplinarnej literatury przedmiotu, obejmujący łącznie prawie 250 (dokładnie 247) pozycji, z czego połowę (124 pozycje) stanowią książki, nierzadko wielotomowe. Godzi się zauważyć, że obok dominującej literatury naukowej w języku polskim są tu też (w liczbie od 1 do 3) prace w językach obcych: angielskim, francuskim, niemieckim, rosyjskim i czeskim. Tak rozległy zestaw bibliograficzny gwarantuje solidne osadzenie rozprawy w interdyscyplinarnej problematyce humanistycznej.

G. Gruntowność, wielostronność i precyzja opisu, analizy i interpretacji (autorka przedstawiła szczegółową charakterystykę genologiczną dedykacji: listu dedykacyjnego, przedmowy dedykacyjnej), omówiła genezę 
i semantykę leksemu dedykacyja i innych XVI- i XVII-wiecznych nazw dedicationis, jak: poświq̨canie, poświęcenie, ofiarowanie, przywłaszczenie i przypisanie, wnikliwie zanalizowała i zinterpretowała grafię i interpunkcję dedykacji jako przejawów tekstotwórczych operacji nadawcy, wreszcie szczegółowo zaprezentowała (też w płaszczyźnie diachronicznejw kolejnych wydaniach uwzględnionych dzieł) dedykacje towarzyszące trzem ważnym z różnych względów (kulturowych, historycznoliterackich, historycznojęzykowych itd.) tekstom: Artykutom prawa majdeburskiego Bartłomieja Groickiego, Gofredowi Torquata Tassa w przekładzie Piotra Kochanowskiego i pierwszej polskiej książce kucharskiej - Compendium ferculorum Stanisława Czernieckiego.

H. Wreszcie, jako skutek wyżej wyliczonych walorów, ważne i interesujące wyniki naukowe. Jest ich wiele i każdy znajdzie wśród nich takie, które go zainteresują w sposób szczególny. Dla historyka języka - badacza zapożyczeń leksykalnych - ważne jest to, że, jak wynika z analiz autorki, rodzaj czcionki (antykwa lub kursywa wobec, np., szwabachy) może - oczywiście obok innych przesłanek - świadczyć o tym, czy w świadomości językowej epoki określona forma wyrazowa lub wyrażeniowa była odczuwana (traktowana) jako obcy wtręt czy już jako choćby najbardziej wstępnie zasymilowany składnik zasobu leksykalnego polszczyzny. Dla historyka literatury z jednej, a historyka polskiej pisowni z drugiej strony ważnym wynikiem naukowym rozprawy jest obserwacja autorki, ,że zmiany parametrów czcionki, stopnia i kroju pisma odgrywają ważną rolę w kompozycji wypowiedzi, w jej wyrazie artystycznym i znaczeniowym. Każda taka zmiana jest relewantna w procesie komunikacji tekstowej, wydobywa określone warstwy czy pokłady komunikatu" [Tutak 2013: 173]. Zmiana wielkości (stopnia) czcionki pozwalała też na odróżnienie tekstu pobocznego (np. glos na marginesach, pełniących funkcję dzisiejszych przypisów bibliograficznych) od tekstu głównego, a także pełniła złożoną i rozbudowaną funkcję grzecznościową. Spośród wyników w obszarze interpunkcji za najważniejsze uznałbym uwypuklenie roli dwukropka: „Każdy ze znaków interpunkcyjnych stanowił ważne narzędzie retoryczne, nadawca podporządkowywał użycie owych znaków swoim celom i intencjom komunikacyjnym. Jednak szczególnie uprzywilejowany pod tym względem był dwukropek. Można go chyba uznać za najbardziej charakterystyczny znak interpunkcji retoryczno-intonacyjnej. Jego podstawowa funkcja polegała na spajaniu członów okresu retorycznego, na wydobywaniu ich jedności semantycznej i intonacyjnej. [...]. Sygnalizował granicę treściowo-syntaktyczną między przytoczeniem a wypowiedzią wprowadzającą [...]. Wresz- 
cie dwukropek wydobywał antytetyczny charakter sąsiadujących z sobą segmentów. Takie były podstawowe (meta)tekstowe funkcje dwukropka. Znak ten mógł też pełnić funkcje poboczne, na przykład występował jako ekwiwalent pytajnika i często sygnalizował wyrazy skrócone" [Tutak 2013: 17]. Bardzo ważny jest też najogólniejszy „genologiczny” wynik rozprawy: teza o relatywnie niższym od oczekiwanego stopniu skonwencjonalizowania dedykacji XVI i XVII wieku: w istocie każda z nich stanowi odrębny i oryginalny twór, co oddala perspektywę przyszłej syntezy.

I. Na koniec językowo-stylistyczny kształt rozprawy, czyli - innymi słowy zalety stylu autorki, która pisze sprawnie, poprawnie, atrakcyjnie i zajmująco (co już dziś, zwłaszcza w pokoleniu autorki, bardzo rzadkie).

Nienaganna pod względem metodologicznym, oparta na solidnej podstawie źródłowo-materiałowej, erudycyjna i perfekcyjna merytorycznie książka Kingi Tutak winna stać się lekturą obowiązkową każdego historyka języka polskiego, badacza literatury staropolskiej i specjalisty z zakresu historii polskiej kultury intelektualnej i artystycznej.

Bogdan Walczak

\section{Bibliografia}

Kuźmicki Marcin, Osiewicz Marek, red. (2010), Dokument pisany w badaniach historyka języka polskiego. Z badań nad grafia i fonetyka historycznej polszczyzny, Oficyna Wydawnicza Uniwersytetu Zielonogórskiego, Zielona Góra-Poznan.

Lisowski Tomasz (2001), Grafia druków polskich z 1521 i 1522 roku. Problemy wariantywności i normalizacji, Wydawnictwo Naukowe UAM, Poznań.

Osiewicz Marek (2013), Wariantywność graficzna „Ksiag o gospodarstwie” Piotra Krescentyna z 1549 roku: studium przypadku, Rys, Poznan.

Tutak Kinga (2013), O dedykacjach polskich XVI i XVII w. (grafia i interpunkcja), Księgarnia Akademicka, Kraków. 